\title{
UNDERSTANDING REGIONAL PRODUCT CHARACTERISTICS AND CONSUMERS PURCHASING THEM IN THE CZECH REPUBLIC
}

\author{
Michal Stoklasa ${ }^{1}$ Eva Pitrunová ${ }^{1}$ \\ ${ }^{1}$ Department of Economics and Public Administration, School of Business Administration in Karviná, Silesian \\ University in Opava, Univerzitní náměstí 1934/3, 73340 Karviná, Czech Republic
}

Link to this article: https://doi.org/10.11118/actaun202068010243

Received: 11. 2. 2019, Accepted: 20. 11. 2019

To cite this article: STOKLASA MICHAL, PITRUNOVÁ EVA. 2020. Understanding Regional Product Characteristics and Consumers Purchasing them in the Czech Republic. Acta Universitatis Agriculturae et Silviculturae Mendelianae Brunensis, 68(1): 243-253.

\begin{abstract}
This article deals with regional products in the Czech Republic. The goal is to examine the regional product characteristics, purchasing behavior when buying said products and basic segmentation criteria of their consumers. After an analysis of WoS and Scopus articles focusing on regional brands, we have concluded that areas explaining how consumers understand regional products (their characteristics), purchasing behavior and basic segmentation criteria are under-researched. Thus we have planned our research to tackle these areas. Our sample consists of 1050 respondents from the Czech Republic, gathered through questionnaire by professional agency Ipsos. We use ChiSquare test to test data, Kolmogorov-Smirnov test to test data distribution, Kruskal-Wallis test to test dependencies, and post-hoc pairwise comparison to test groups. Main results include: consumers assign different importance to regional product characteristics than regional brands communicate; most positive toward regional brands are age groups $36-45$ and 26-35, university education, from Moravia or Silesia, least positive are youngest and oldest age group, with secondary education. We propose regional brands to utilize this knowledge when designing their communication.
\end{abstract}

Keywords: regional brand, regional product, regional product characteristics, purchasing behaviour, regional product availability, Kruskal-Wallis test, Czech Republic

\section{INTRODUCTION}

Regional products and regional brands are evolving to meet the needs of $21^{\text {st }}$ century consumers accepting the new technologies into their purchasing behaviour and thus requiring change even from traditional local products. We have examined Web of Science and Scopus databases to understand the past and current research trends of regional brands to be able to define our own future research into the topic, see Stoklasa and Pitrunová (2018). The results of this endeavour can be summed up in two statements: regional brands are academically important in Central Europe and China; although the topic is researched for well over a decade, the fundamental theoretical basis (definitions) is not settled upon. By examining each article from the past 10 years in WoS and Scopus, we came up with several conclusions. Majority of academics have focused and are still focusing on the awareness of regional brands. Mostly the consumers claim that they are aware of these brands, but in reality they are confused with various product protective brands and have no idea, what these mean (guarantee). We do not want to follow this trend, as we think the results would be the same as in other articles, but we would rather focus on what consumers understand as regional products, what are the characteristics of said products and what characteristics have the consumers buying 
them. We have also examined the online presence of regional brands (Pitrunová and Stoklasa, 2018) and formulated keywords that regional brands use to promote their products to consumers. We want to compare it with how consumers perceive regional products.

Thus the aim of this article is to examine the regional product characteristics, purchasing behavior when buying said products and basic segmentation criteria of their consumers. This will allow us to create basic guidelines for brands, how they should segment their customers, what to tell each segment and how to understand their purchasing behavior. We want to tackle this goal through questionnaire research in the Czech Republic.

\section{Current State of Regional Brands in Research}

In this chapter we want to define regional brand and provide background about the current state of regional brand research.

\section{Defining Regional Brand}

The American Marketing Association defines the brand as 'name, term, design, symbol, or any other feature that identifies one seller's good or service as distinct from those of other sellers.' (AMA, 2019). Many (famous) authors use this definition and build on it (Kotler and Keller, 2007; Pelsmacker, Geuens and Bergh, 2003). The brand is a feature of a product or service that helps to differentiate it in some way from other products and services on the market satisfying the same needs (Kotler and Keller, 2007).

Doležalová (2007) explains that product quality branding was built on the brands guaranteed by the state. Government institution, which set the rules and enforced them, guided the small producers thus warranting certain product characteristics to the consumers. This allowed for the creation of brand programs, previously separate brands that use the same criteria, which were the foundation for regional brands and brand programs. In the reality of the Czech market, this has however led to creation of hundreds of different brands and brand programs, culminating in situation where consumers are confused and actually know the meaning of fewer brands (Pitrunová and Stoklasa, 2018).

Čadilová (2011), former head of our biggest and fastest growing regional brand program - Association of Regional Brands, helped to define regional brands in the Czech Republic. Regional brands want to help the region by making the products more visible and available to the local public and tourists. Regional brands help the region economically, culturally, socially and environmentally. 'Branded products, their promotion and sale, and perhaps a possibility to meet the producers in person and visit workshops or farms strengthen the region's attractiveness for tourists, form its character and have a positive impact on perceiving the region as a whole' (Čadilová, 2011).

\section{Web of Science and Scopus Research}

Authors have examined Web of Science and Scopus databases to understand the past and current research trends of regional brands to be able to define their own future research into the topic. In the past 10 years, 86 and 148 articles have been published in both databases, however only 61 and 9 articles are relevant to our understanding of regional brands. The main reason is that regional brands aren't yet fully agreed upon and don't have any widely accepted definition. Kašková and Chromý (2014) state that the reason is their novelty. Even quality literature reviews, such as by Chalupová and Prokop (2016) don’t provide comprehensive definition. They are sometimes understood as brands of whole regions, i.e. marketing of a geographical area. In WoS it's mainly Asian (China, see further) authors (Li, 2016; Hong and Liang, 2014; Liu, Gao and Sun, 2014) where we understand it as a tool to describe how the name of the region is represented on the outside, and consequently how it influences the success of its products. This approach to regional brands is coupled with the issues of country of origin and region of origin, with which Chinese have to deal a lot more than other countries. In Scopus its 31 articles (Lucarelli, 2018; Donner et al., 2017). 26 regional brand articles are about local wine brands (Bonn, Cho and Um, 2018; Thomas, Quintal and Phau, 2018).

The other point of view is our approach to regional brands, meaning regional brand is a tool how to help small producers get their product to customers, while preserving its nature, origin and helping the region as a whole. Czech-Slovak articles (13) with occasional Polish (1), Austrian (1), German (1) article, where we understand regional brands as brands of local regional products produced by micro-companies and craftsman (Pícha and Skořepa, 2018; Zuffova, Bohatova and Bumbalova, 2017; Pícha, Navrátil and Švec, 2018).

Margarisová and Vokáčová (2016) did a comprehensive study on the use of brand and building brand value specifically for regional brands. The authors utilize similar theoretical basis as we did (Aaker, Kotler, Keller, Vysekalová) and have formulated the so called House of Regional Brand. Foundation is the theory by Aaker, 2003 for strategic brand analysis and brand identity system; Azoulay, Kapferer, 2003 for Kapferer's Brand Identity Prism; Keller, 2007 for tools and brand building goals; Kotler, Armstrong, 2006 for macro and micro environment analysis; Přibová, Mynářová, Hindls, Hronová, 2000 for brand conceived as a system, in which individual attributes are arranged into certain levels of a pyramid scheme; Vysekalová, 2004 for the concept of total brand.

As we have stated in our previous paper (Stoklasa and Pitrunová, 2018), examining these articles leads us to the conclusion that consumers are 
confused with various product protective brands, including regional brands, and have no idea, what these brands guarantee. This topic is supported by extensive research, therefore the authors believe that it would not bring much value to pursue it as well. Although the consumers do not follow product protective branding, they do prefer local (regional) products. Therefore, we should still focus on this preference and examine what regional products mean to consumers. We should also focus on the characteristics of the consumers themselves, as our past research indicates (Stoklasa, 2015) there are certain demographic groups with higher preference of local products. Chalupová and Prokop (2016) directly support our conclusions with their study about regional food labels awareness and media presence.

\section{MATERIALS AND METHODS}

This chapter is divided into two subchapters, where we explain our research logic, research process and characterize our sample.

\section{Research Logic and Process}

The research logic was based on our previous, almost 10 years, experience with the issue researchers often only focus on regional brand awareness, and the results are crushingly same, consumers don't know regional brands although they purchase or would like to purchase regional products. These questions are only describing the current status and are not helping the brands to improve. Our questionnaire was thus designed to omit the usual questions about awareness and brand recognition, but rather focus on what regional products represent for consumers and consumers' perception towards them. We want to understand how consumers perceive quality products, what are the important characteristics of regional products, who are the consumers purchasing them, general purchasing behaviour when buying these products, and how technology is changing it. Because of this, the questionnaire consists of 3 distinct parts, each focused on a subtopic: product quality, battery of questions on product characteristics and purchasing behaviour, and another battery on technology. In this article we will use the results of our first battery. It uses Likert scale from strongly agree to strongly disagree. The questionnaire was introduced with a thorough description of regional brands and regional products (with logos, pictures and plenty of text), to make sure our respondents are certain about the topic and our terminology.

To fulfil our goal, we are following this logic for our econometric statistical testing: first we need to understand, which basic sample characteristics affect research results, second we need to understand data distribution that will affect the used testing methods, third we need to test the dependencies of selected questions of chosen sample characteristics, fourth we need to find out how are the characteristics affecting our results. For this process, we will use one-way Chi-Square test of good compliance to test basic sample characteristics. One sample Kolmogorov-Smirnov test to test data distribution, if a variable follows normal distribution. To test the dependencies, we will use based on the data distribution either Chi-Square, ANOVA, or Kruskal-Wallis test. However, these tests only show the dependency, so we will need to use one of the post-hoc tests to understand which group of factors is influencing the results (Saunders, Lewis and Thornhill, 2009; Murakami and Lee, 2015).

We have formulated these working hypotheses:

- Hypothesis 1: There is an impact of sample identifiers (age, gender, education, and region) on research results.

- Hypothesis 2: The perception of regional products is affected by consumers' identifying factors.

- Hypothesis 3: The purchasing behaviour when buying regional products is affected by consumers' identifying factors.

- Hypothesis 4: The perception of availability of regional products is affected by consumers' identifying factors.

\section{Sample Characteristics}

Our sample consists of 1050 questionnaires gathered by professional marketing agency Ipsos in January 2019 in the Czech Republic. According to the research agency, the sample is representative, Ipsos CASI panel with over 100000 respondents is used. The sample has following basic characteristics, see Tab. I and II. We also use size of the place of residence, and frequency of online purchases as our identifiers, however these are not shown here due to their irrelevance to our goal and space constraints.

I: Sample profile-gender, age, education

\begin{tabular}{|c|c|c|c|}
\hline Criterion & Group & $\begin{array}{l}\text { Absolute } \\
\text { frequency }\end{array}$ & $\begin{array}{c}\text { Relative } \\
\text { frequency }\end{array}$ \\
\hline \multirow{2}{*}{ Gender } & Male & 536 & 51.05 \\
\hline & Female & 514 & 48.95 \\
\hline \multirow{5}{*}{ Age } & $18-25$ & 166 & 15.81 \\
\hline & $26-35$ & 202 & 19.24 \\
\hline & $36-45$ & 216 & 20.57 \\
\hline & $46-55$ & 179 & 17.05 \\
\hline & $56-65$ & 287 & 27.33 \\
\hline \multirow{4}{*}{ Education } & Primary & 115 & 10.95 \\
\hline & Skilled & 375 & 35.71 \\
\hline & Secondary & 398 & 37.90 \\
\hline & University & 162 & 15.43 \\
\hline
\end{tabular}

Source: own calculation 
II: Sample profile - region

\begin{tabular}{|c|c|c|c|c|c|}
\hline Region & Abs. frequency & Region & Abs. frequency & Region & Abs. frequency \\
\hline Jihočeský & 60 & Moravskoslezský & 124 & Stř̌edočeský & 129 \\
\hline Jihomoravský & 109 & Olomoucký & 59 & Ústecký & 93 \\
\hline Královehradecký & 52 & Pardubický & 54 & Vysočina & 48 \\
\hline Karlovarský & 25 & Praha & 149 & Zlínský & 63 \\
\hline Liberecký & 37 & Plzeňský & 48 & & \\
\hline
\end{tabular}

Source: own calculation

Our econometric statistical testing starts with the test of the basic sample characteristics. The test used will be a one-way Chi-Square test of good compliance. We will test all the necessary sample identifying characteristics, such as age, gender, region and education. The observed frequencies and the expected frequencies are the starting point. The test is performed at a significance level $a=0.05$, i.e. $5 \%$. Due to space constraints, we format these 4 separate hypothesis into one line.

- HO: Age / gender / region / education do not affect research results.

- H1: Age / gender / region / education affect research results.

III: Chi-Square results for sample identifying characteristics

\begin{tabular}{lcccc}
\hline & Age & Gender & Region & Education \\
\hline Chi-Square & 30.990 & 0.461 & 256.933 & 239.516 \\
df & 4 & 1 & 13 & 3 \\
Asymp. Sig & 0.000 & 0.497 & 0.000 & 0.000 \\
\hline
\end{tabular}

Source: own calculation

The test criterions are 30.990, 0.461, 256.933 and 239.516, see Tab. III. The value of Sig. 0.000 is less than the set value of significance level, we reject the zero hypothesis (HO) on the independence of individual characters, and we accept the alternative $\mathrm{H} 1$ hypothesis that there is a certain influence of the age, region and education on the research results. Only for gender the Sig. is 0.497 and we accept the zero hypothesis. Therefore, it is possible to expect that the age, region and education have an impact on the results of the research and it is advisable to further test it. Based on our previous research (Stoklasa, 2015) we were shocked by the results for gender and have tested all of the questions by twoway Chi-Square anyway and have confirmed this result.

\section{RESULTS}

This chapter is divided into two sub-chapters, where we first present our general results and then continue with econometric statistical testing.

\section{General Presentation of Research Results}

For this article we are focusing on our first battery consisting of 19 statements where respondents can specify their level of agreement on five-level Likert scale, see Tab. IV. For our interpretation, we also use the logic of primary school grading where 1 (strongly agree) is best and 5 (strongly disagree) is worst. Our intention with the whole battery wasn't to measure the purchases/sales, but to rather get the idea about consumer perception.

The battery is introduced with a general statement regarding the purchase of regional products. The average is 2.6 with $43.9 \%$ of respondents purchasing regional products and $45.9 \%$ of neutral answers. We understand these results as people who purchase not only regional products but also are also regularly shopping in retail chains.

The block of questions 2-7 is focused on regional product characteristics. The statements were formulated based on our previous article about regional brand online presence (Pitrunová and Stoklasa, 2018), where we found out what are the most common regional product characteristics that the brands communicate to consumers. The results are quite frankly shockingly negative if we put them in perspective with what the brands are trying to stress out in their communication. Regional products are of high quality is a founding statement used by all regional brands, but it scored only $44.2 \%$ of positive answers and an average of 2.6. Regional products are more expensive scored $43.2 \%$ of positive answers and an average of 2.6. Regional products are environmentally friendly is again a founding statement used by every regional brand, yet is scored only $25.9 \%$ positive answers and an average of 2.9. Regional products support the region is widely accepted by our respondents with $69.1 \%$ of positive answers and an average of 2.2, although paradoxically this statement isn't promoted by the brands themselves. Regional products are made in the traditional way scored $46.9 \%$ positive answers and an average of 2.5. Regional products are unique scored $56.3 \%$ of positive answers and an average of 2.4 .

The block of questions 8-13 is focused on general purchasing behaviour highly relevant to regional products. Statement I buy/would buy regional products even if they were more expensive was 
included to show us whether consumers are willing to spend more money on higher quality, it scored $32.3 \%$ of positive answers and an average of 2.8. I read product composition was answered positively by $52 \%$ of respondents with an average of 2.5. Tenth statement was included as a respondent check for price acceptance, it scored 54\% of positive answers and an average of 2.4. An award, certificate or quality label was often times stated in other research as one of the most important factors showing the consumers that a product is of a higher quality, our sample has for this question only $38.7 \%$ of positive answers and an average of 2.8 . Marketing communication is one of the essentials helping to boost sales, our sample doesn't consider it essential for regional products with only 13.4\% of positive answers and an average of 3.5. Another fact often appearing in other research is consumers blindly believing in awards/certificates, our sample has only $26.6 \%$ of positive answers and an average of 3.0 .

The third block of questions $14-16$ is focused on availability (distribution). Where we asked whether the products should be only available in specialized stores, which was met with $48.8 \%$ of negative answers and an average of 3.4. Consumers want to purchase regional products in supermarkets, $59.6 \%$ of positive answers and an average of 2.3, and on the internet, $54.5 \%$ of positive answers and an average of 2.4. Our colleagues Bauerová and Klepek (2018) argue, that the requirement of online shopping can be explained through Technology Acceptance.

IV: All statements and their results (results are relative frequency in \%)

\begin{tabular}{|c|c|c|c|c|c|c|}
\hline No. & Statement & $\begin{array}{c}\text { Strongly } \\
\text { agree }\end{array}$ & Agree & Neutral & Dis-agree & $\begin{array}{l}\text { Strongly } \\
\text { disagree }\end{array}$ \\
\hline 1 & I buy regional products & 7.1 & 36.8 & 45.9 & 6.7 & 3.5 \\
\hline 2 & $\begin{array}{l}\text { The regional product is of high quality, made of quality raw } \\
\text { materials }\end{array}$ & 7.3 & 36.9 & 45.7 & 7.8 & 2.3 \\
\hline 3 & The regional product is more expensive & 9.4 & 33.8 & 43.1 & 11.4 & 2.2 \\
\hline 4 & The regional product is environmentally friendly & 5.3 & 20.6 & 58.8 & 12.6 & 2.8 \\
\hline 5 & The regional product supports the region & 24.6 & 44.5 & 23.2 & 5.6 & 2.1 \\
\hline 6 & The regional product is made in the traditional way & 8.1 & 38.8 & 44.9 & 6.8 & 1.5 \\
\hline 7 & $\begin{array}{l}\text { The regional product is unique, something original, special, } \\
\text { peerless }\end{array}$ & 12.7 & 43.6 & 33.8 & 8.0 & 1.9 \\
\hline 8 & $\begin{array}{l}\text { I bought / would buy the regional product, even if it was more } \\
\text { expensive than the other products in that category }\end{array}$ & 6.7 & 25.6 & 49.6 & 14.4 & 3.7 \\
\hline 9 & $\begin{array}{l}\text { When purchasing common goods (e.g. yoghurt) I read } \\
\text { the composition of the product }\end{array}$ & 17.4 & 34.6 & 30.5 & 11.8 & 5.7 \\
\hline 10 & $\begin{array}{l}\text { I am willing / would be willing to pay more for the higher } \\
\text { quality of the product }\end{array}$ & 13.0 & 41.0 & 35.2 & 8.2 & 2.6 \\
\hline 11 & $\begin{array}{l}\text { When making purchasing decisions, it is very important } \\
\text { if the product has an award, a certificate, a quality label }\end{array}$ & 6.8 & 31.9 & 41.3 & 16.2 & 3.8 \\
\hline 12 & $\begin{array}{l}\text { When making purchasing decisions, it is very important } \\
\text { if the product is in advertisement / is known }\end{array}$ & 2.7 & 10.7 & 33.9 & 35.1 & 17.6 \\
\hline 13 & $\begin{array}{l}\text { If the product has an award / certificate, I believe it and do not } \\
\text { look for further information }\end{array}$ & 4.9 & 21.7 & 45.6 & 22.4 & 5.4 \\
\hline 14 & $\begin{array}{l}\text { Regional products should only be available in specialized } \\
\text { stores or on farmer markets }\end{array}$ & 5.1 & 14.1 & 31.9 & 35.1 & 13.7 \\
\hline 15 & $\begin{array}{l}\text { Regional products should be available for purchase } \\
\text { in supermarkets }\end{array}$ & 17.0 & 42.6 & 33.0 & 4.0 & 3.3 \\
\hline 16 & $\begin{array}{l}\text { Regional products should be available for purchase over the } \\
\text { internet }\end{array}$ & 12.8 & 41.7 & 36.4 & 6.9 & 2.3 \\
\hline 17 & $\begin{array}{l}\text { To buy quality products, I am willing to look for specialized } \\
\text { stores }\end{array}$ & 8.5 & 37.8 & 37.2 & 13.4 & 3.0 \\
\hline 18 & I visit farmer markets or other fairs & 9.2 & 34.0 & 34.0 & 18.1 & 4.7 \\
\hline 19 & $\begin{array}{l}\text { I like tasting/sampling products for free, e.g. in shops, } \\
\text { in the square }\end{array}$ & 13.0 & 34.4 & 35.9 & 13.0 & 3.7 \\
\hline
\end{tabular}

Source: own calculation 
The last block of question 17-19 is focused on purchasing behaviour connected with availability. Consumers are willing to look for specialized stores to buy quality products, $46.3 \%$ of positive answers and an average of 2.6. They visit farmer markets, $43.3 \%$ of positive answers and an average of 2.7 . And they like tasting/sampling products for free with $47.4 \%$ of positive answers and an average of 2.6.

From the distribution of answers and from the averages, we can see how the consumers' opinions vary. None of the averages was overwhelmingly positive, our lowest is 2.2 , but the majority is closer to 3 and some are over, which suggests more negative answers than positive. Consumers were rather cautious to state their agreement with our statements. In the data tables, we could observe how different sample identifiers affect answers but it needs to be proven statistically.

\section{Econometric Statistical Testing}

First, we start with one sample KolmogorovSmirnov test to test the data distribution, if a variable follows normal distribution. We are not including the table with data due to space constraints, but all the Asymp. Sig. (2-tailed) are 0.000, which means we reject null hypothesis about normal distribution of data and accept alternative hypothesis that data doesn't have normal distribution and we can't use ANOVA and have to use Kruskal-Wallis test. All the normal parameters, most extreme differences and test statistics in the K-S test support the result.

The non-parametric Kruskal-Wallis test is used to test the working hypothesis on the overall perception of regional products and chosen sample identifiers. The hypothesis, once converted to the statistical hypothesis, will be as follows:

- H0: The perception of regional products is not dependent on consumers' identifying factors.

- H1: The perception of regional products is dependent on consumers' identifying factors.

Questions No. 2, 3, 4, 5, 6 and 7 and identifying factors (age, education, region) are tested. The test is performed at a significance level $\alpha=0.05$, i.e. $5 \%$. The results of Kruskal-Wallis test shown in Tab. V point out that we cannot reject null hypothesis and have to state that the perception of regional products is not dependent on consumers identifying factors. The authors refrain from using the term "partially accept", however we must state that several results show significant effect of identifying factors and are worthy to be further tested by post-hoc test, in this case pairwise comparison, see below in discussion.

The non-parametric Kruskal-Wallis test is then used to test the working hypothesis on the overall purchasing behaviour when buying regional products and chosen sample identifiers. The hypothesis, once converted to the statistical hypothesis, will be as follows:

- H0: The purchasing behaviour when buying regional products is not dependent on consumers' identifying factors.

- H1: The purchasing behaviour when buying regional products is dependent on consumers' identifying factors.

V: Kruskal-Wallis results for the first block of questions No. 2-7

\begin{tabular}{llcccccc}
\hline \multicolumn{1}{c}{ Identifier } & \multicolumn{1}{c}{ Results } & Q. 2 & Q. 3 & Q. 4 & Q. 5 & Q. 6 & Q. 7 \\
\cline { 3 - 8 } Age & Kruskal-Wallis H & 7.013 & 2.215 & 7.794 & 4.522 & 6.932 & 12.114 \\
& Asymp. Sig. & 0.135 & 0.696 & 0.100 & 0.340 & 0.140 & 0.017 \\
\hline \multirow{2}{*}{ Education } & Kruskal-Wallis H & 5.182 & 0.808 & 3.933 & 33.662 & 1.090 & 17.731 \\
& Asymp. Sig. & 0.159 & 0.848 & 0.269 & 0.000 & 0.779 & 0.000 \\
\hline \multirow{2}{*}{ Region } & Kruskal-Wallis H & 20.228 & 18.001 & 9.388 & 23.141 & 19.345 & 17.280 \\
\hline & Asymp. Sig. & 0.090 & 0.157 & 0.743 & 0.040 & 0.113 & 0.187 \\
\hline
\end{tabular}

Source: own calculation

VI: TKruskal-Wallis results for the second block of questions No. 8-13

\begin{tabular}{llcccccc}
\hline \multicolumn{1}{c}{ Identifier } & \multicolumn{1}{c}{ Results } & Q.8 & Q.9 & Q.10 & Q.11 & Q.12 & Q. 13 \\
\multirow{2}{*}{ Age } & Kruskal-Wallis H & 6.050 & 15.388 & 5.876 & 2.256 & 10.662 & 4.743 \\
& Asymp. Sig. & 0.195 & 0.004 & 0.209 & 0.689 & 0.031 & 0.315 \\
\hline \multirow{2}{*}{ Education } & Kruskal-Wallis H & 5.346 & 38.376 & 29.076 & 5.861 & 20.663 & 6.526 \\
& Asymp. Sig. & 0.148 & 0.000 & 0.000 & 0.119 & 0.000 & 0.089 \\
\hline \multirow{2}{*}{ Region } & Kruskal-Wallis H & 14.162 & 20.333 & 17.789 & 8.345 & 9.658 & 8.250 \\
& Asymp. Sig. & 0.363 & 0.087 & 0.166 & 0.820 & 0.722 & 0.827 \\
\hline
\end{tabular}

Source: own calculation 
VII: Kruskal-Wallis results for the third block of questions No. 14-19

\begin{tabular}{llcccccc}
\multicolumn{1}{c}{ Identifier } & \multicolumn{1}{c}{ Results } & Q. 14 & Q. 15 & Q.16 & Q. 17 & Q. 18 & Q. 19 \\
\cline { 2 - 8 } Age & Kruskal-Wallis H & 7.946 & 3.438 & 9.927 & 5.009 & 9.771 & 25.182 \\
& Asymp. Sig. & 0.094 & 0.487 & 0.042 & 0.286 & 0.044 & 0.000 \\
\hline \multirow{2}{*}{ Education } & Kruskal-Wallis H & 31.626 & 9.459 & 18.117 & 13.581 & 0.266 & 7.030 \\
& Asymp. Sig. & 0.000 & 0.024 & 0.000 & 0.004 & 0.966 & 0.071 \\
\hline \multirow{2}{*}{ Region } & Kruskal-Wallis H & 12.012 & 17.893 & 23.246 & 21.765 & 19.788 & 20.185 \\
& Asymp. Sig. & 0.527 & 0.162 & 0.039 & 0.059 & 0.100 & 0.091 \\
\hline
\end{tabular}

Source: own calculation

Questions No. 8, 9, 10, 11, 12 and 13 and identifying factors (age, education, region) are tested. The test is performed at a significance level $\alpha=0.05$, i.e. $5 \%$.

The results of Kruskal-Wallis test shown in Tab. VI point out that we cannot reject null hypothesis and have to state that the purchasing behaviour of regional products is not dependent on consumers identifying factors. Again, some results show significant effect of identifying factors and are worthy to be further tested by post-hoc test, see below in discussion.

The non-parametric Kruskal-Wallis test is then used to test the working hypothesis on the overall perception of availability of regional products and chosen sample identifiers. The hypothesis, once converted to the statistical hypothesis, will be as follows:

- H0: The perception of availability of regional products is not dependent on consumers' identifying factors.

- H1: The perception of availability of regional products is dependent on consumers' identifying factors.

Questions No. 14, 15, 16, 17, 18 and 19 and identifying factors (age, education, region) are tested. The test is performed at a significance level $\alpha=0.05$, i.e. $5 \%$.

And again, the results of Kruskal-Wallis test shown in Tab. VII point out that we cannot reject null hypothesis and have to state that the perception of availability of regional products is not dependent on consumers identifying factors. And again, some results show significant effect of identifying factors and are worthy to be further tested by post-hoc test, see below in discussion.

Although we have formally accepted the null hypotheses about independency of the variables, we have chosen our testing process because we can find in post-hoc testing, how are the identifying factors influencing our result. Out of the 18 tested cases, if we take into account common significance level $\alpha=0.1$, i.e. $10 \%$, age was influencing our results in 8 cases, education in 11, and region in 7, that is overall $48 \%$ of our tests.

\section{DISCUSSION}

This chapter is divided into two blocks, discussion about general results and statistical testing.

\section{General Results and Recommendations}

In general, we want to state that according to our results in question 1, consumers purchase regional products, these products have a strong place in their shopping cart, but are obviously not the only products that consumers purchase. The trend is, however, rather positive. In just 5 years, we have instead of 31\% (Stoklasa, 2015) almost 44\% consumers purchasing these products. Our results are in line with what other authors report (Chalupová and Prokop, 2016).

Based on our research about regional brand online presence (Pitrunová and Stoklasa, 2018), we have found out which key words the brands use to describe their products. Our current research puts this into perspective with the consumers' opinion. Brands use 'quality product', 'environmentally friendly', 'traditional' the most. Some brands add 'unique' and 'supporting the region'. None use 'more expensive'. Consumers however would rank 'supporting the region' the highest, then 'unique', 'traditional', 'more expensive', 'quality', and 'environmentally friendly', see results for question 2-7. We are recommending the brands to consider this and start describing the regional products as such: "unique traditional products, which are bit more expensive but only because they support the region, are of good quality and environmentally friendly'. We assume that it can be used nicely in the House of Regional Brand Model by Margarisová and Vokáčová (2016) as product attributes (strategic product traits) that fuel brand values manifested on the outside to the community.

In the block about purchasing behaviour when buying regional products, we have intentionally included two questions about price acceptance (Czechs are price sensitive, although they state otherwise in studies - Špačková, 2018), following our one price trait from the first block (regional products are more expensive, q. No. 3). Consumers are willing to pay more for higher quality of products (q. No. 10), regional products have higher quality (q. No. 2), and consumers would buy the regional product, even if it was more expensive (q. No. 8), although there are other product characteristics, that may play a role here. For brands, it is a clear sign, that the higher price is accepted and justifiable by consumers. We are pleasantly surprised, that consumers read product composition. This fact is an important opportunity 
not used by many regional brands, therefore we recommend to use product packaging to inform consumers about the ingredients. For example bread roll, that majority of Czechs eat every day, from Tesco contains several dozens ingredients (Tesco, 2019) but regional only three (Regionalnipotravina, 2018). Although our respondents think that awards and certificates are important, they are reluctant to look for additional information about the award. We would therefore recommend, and with our experience (Stoklasa, 2015), to only include one regional brand and not confuse consumers with other certificates, quality labels and such. The whole consumer confusion with the amount of product protective branding should be managed by the government, ideally through Ministry of Agriculture and their brand Regionalní potravina. Last point in this block is a shocking one, since our respondents don't think that being in advertisement is important. These results and recommendations are in line with other articles (Chalupová and Prokop, 2016).

The last block was focused on perception of availability, where respondents strongly voiced that regional products should not be only available in specialized stores and farmers markets, but should also be available for purchase in regular supermarkets and on the internet. This is a delicate issue, since the basic principles of regional products don't allow them to be used in intensive distribution, but it would be convenient for consumers. There are first tries of regional product supermarkets, such as Trefa (Trefa, 2019), and there are also first tries to include regional products in multinational retail chains, such as Billa (Přibík, 2015), but both tries don’t fulfil the consumers wish. Out of all the examined regional brands, only 2 have e-shop (Pitrunová and Stoklasa, 2018). We can't recommend any radical changes due to the principles how these brands operate (see Stoklasa, 2015), however we would argue that evolution is needed. We are proposing an integration of internet into the traditional specialized stores and markets, in a way that Farmadomů is set up, i.e. consumers can browse products and order them 24/7 but have to physically get them during 1 or 2 days a week in a specialized store (Farmadomů, 2019). After all, our respondents stated that they are willing to look for specialized stores to buy quality products, and visit farmers markets.

\section{Segmentation Results and Recommendations}

Based on our research results, we would like to state that using identifiers such as age, education and region is beneficial for regional brands. It is best to use age and mainly education for regional characteristics and purchasing behaviour, region for availability.

K-W post-hoc test using pairwise comparison, Dunn's test with Bonferroni correction, can find the statistically significant differences, rank the groups and assign values. We use it to find for example which age group is influencing our results and how.

Our presumption was that with higher age the results would be more positive towards the regional products. However the data and tests show, that the youngest and oldest of our age groups are the most negative and the most positive are 36-45, followed by 26-35. We can observe this trend in almost all of the statements that show significant effect in K-W test (q. No. 7, 9, 12, 14, 16, 18, 19). We would therefore recommend regional brands to use age in their segmentation and prepare at least two types of messages, one focused on the positive age groups 36-45 and 26-35, and one for the rest. The data also shows that the oldest age group utilizes their life experience the most and differs the most in their opinions about product characteristics (e.g. q. No. 7 about uniqueness). The youngest age group differed the most in their opinions about marketing communication (q. No. 12 they require advertisement), are more price sensitive (q. No. 2, 3 , 8). Two youngest age groups are also more trustful (q. No. 14 about certificates).

Our presumption for education was again linear, with higher education we would get more positive attitude towards regional products. The results are most positive for university education, however followed by primary education, skilled, and secondary education has the worst attitude. There are some exceptions, e.g. in q. No. 5, the worst answers are by primary education. People with higher education are also more time-constrained and have higher preference of more availability options. Respondents with highest education had broader overview of regional products and were looking for more product information. We would again recommend to create at least two different messages, one focused on informed consumers and one on uninformed.

Regional differences were the least statistically important identifier, although a look at the data would suggest otherwise. The Jihočeský region is rather negative in many questions, compared to others (q. No. 2, 5, 9, 17), more sceptical of regional products, their characteristics and availability. The reason may be that regional producers and their products have some tradition in this region, and consumers have negative experience with them (or see no results). At the same time, the promotion of these products may be misunderstood, and consumers have other expectations what supporting regional producers may cause. This issue warrants further investigation and we are unable to provide any recommendations without additional data. Regional products have a very strong connection with traditions especially in the regions of Moravia and also in the Plzeňský, Karlovarský and Královehradecký regions. This may be due to the overall approach of city leaders, associations and regional support in the context of coherence with history. 


\section{CONCLUSION}

This article deals with regional products in the Czech Republic. The goal was to examine the regional product characteristics, purchasing behavior when buying said products and basic segmentation criteria of their consumers. Authors have conducted an analysis of WoS and Scopus articles focusing on regional brands, and have concluded that researchers focus too much on brand awareness although in reality consumers are rather confused by all the product protective branding. But some areas explaining how consumers understand regional products (their characteristics), purchasing behavior and basic segmentation criteria are under-researched. Thus we have planned our research to tackle these areas. Our sample consists of 1050 respondents from the Czech Republic, gathered through questionnaire by professional agency Ipsos. We use Chi-Square test to test data, KolmogorovSmirnov test to test data distribution, Kruskal-Wallis test to test dependencies, and post-hoc pairwise comparison to test groups.

The main results are as follows. Consumers purchase regional products, these products have a strong place in their shopping cart, but are obviously not the only products that consumers purchase. Consumers assign different importance to regional product characteristics than regional brands communicate, thus we have formulated a compromise: 'unique traditional products, which are bit more expensive but only because they support the region, are of good quality and environmentally friendly'. Concerning basic segmentation criteria, the most positive towards regional brands are age groups 36-45 and 26-35, university education, from Moravia or Silesia, least positive are youngest and oldest age group, with secondary education, from Jihočeský region. We propose regional brands to utilize this knowledge when designing their communication (including product packaging). Availability of regional products is a delicate issue, as consumers would like to purchase them in supermarkets and e-shops, but this goes against the basic operating principles of regional brands. We propose a proven concept from Karviná - Farmadomů, which operates basically as an e-shop but with physical purchase.

We are aware of some limitations of our research. As has been proven time and time again, questionnaire research has its limitations, consumers often state one thing but their true purchasing behaviour is different. We were unable to provide solid statistical evidence of how to use region as a segmentation criterion. All this leads us to think that purchasing behaviour when buying regional products warrants further research.

\section{Acknowledgements}

This research was financially supported by the Student grant competition project SGS/7/2017: "Acceptance of technology from the perspective of marketing tools".

\section{REFERENCES}

AAKER, D. A. 2003. Brand building [in Czech: Brand building - budování obchodní značky]. Brno: Computer Press.

AMERICAN MARKETING ASSOCIATION. 2017. Dictionary. American Marketing Association. [Online]. Available at: https://www.ama.org/resources/Pages/Dictionary.aspx?dLetter=B [Accessed: 2019, January 25].

AZOULAY, A. and KAPFERER, J. N. 2003. Do brand personality scales really measure brand personality? Journal of Brand Management, 11(2): 143-155.

BAUEROVÁ, R. and KLEPEK, M. 2018. Technology Acceptance as a Determinant of Online Grocery Shopping Adoption. Acta Univ. Agric. Silvic. Mendelianae Brun., 66(3): 737-746.

BONN, M. A., CHO., M. and UM., H. 2018. The evolution of wine research: A 26 year historical examination of topics, trends and future direction. International Journal of Contemporary Hospitality Management, 30(1): 286-312.

ČADILOVÁ, K. 2011. Regional Branding throughout Europe. Litomyšl: Asociace regionálních značek.

CHALUPOVÁ, M. and PROKOP, M. 2016. Awareness of the Vysočina regional food labels with context of their media presence. Acta Univ. Agric. Silvic. Mendelianae Brun., 64(1): 223-234.

DOLEŽALOVÁ, H. 2007. Goods Knowledge [in Czech: Zbožíznalství]. České Budějovice: Jihočeská univerzita, Ekonomická fakulta.

DONNER, M., HORLINGS, L., FORT, F. and VELLEMA, S. 2017. Place branding, embeddedness and endogenous rural development: Four European cases. Place Branding and Public Diplomacy, 13(4): 273-292.

FARMADOMŮ. 2019. About us [in Czech: O nás]. Farma domů. [Online]. Available at: http://www. farmadomu.cz/o-nas/ [Accessed: 2019, January 27]. 
HONG, F. and LIANG, D. Q. 2014. The Existing Problems and Their Countermeasures of Regional Brand of Intellectual Property Rights Which Affecting the Long-term Development of Regional Economy. In: $2^{N D}$ International Conference on Economic, Business Management and Education Innovation (EBMEI 2014). Singapore, 5-6 November. Singapore: Singapore Management and Sports Science Institute, pp. 262-265.

KAŠKOVÁ, M. and CHROMÝ, P. 2014. Regional product labelling as part of the region formation process. The case of Czechia. AUC Geographica, 49(2): 87-98.

KOTLER, P. and KELLER, K. L. 2007. Marketing management. Prague: Grada Publishing.

KELLER, K. L. 2007. Strategic brand management [in Czech: Strategické ř́zení značky]. Praha: Grada Publishing.

LI, M. W. 2016. Study on How to Build Regional Industrial Clusters Brand. In: $3^{R D}$ International Conference on Economics and Management (ICEM 2016). China, 2-3 July. Suzhou: DEStech, pp. 366370.

LIU, W. C., GAO, Q. Q. and SUN, L. H. 2014. Study on Regional Brand Image: A Perspective of Scale Development. In: International Conference on Economics and Management Engineering (ICEME 2014). China, 18-19 June. Wuhan: DEStech, pp. 415-421.

LUCARELLI, A. 2018. Place branding as urban policy: the (im)political place branding. Cities, 80: 1221.

MARGARISOVÁ, K. and VOKÁČOVÁ, L. 2016. Regional Branding: Building Brand Value. Acta Univ. Agric. Silvic. Mendelianae Brun., 64(6): 2061-2066.

MURAKAMI, H. and LEE, S. K. 2015. Unbiasedness and biasedness of the Jonckheere-Terpstra and the Kruskal-Wallis tests. Journal of the Korean Statistical Society, 44(3): 342-351.

PELSMACKER, P. D., GEUENS, M. and BERGH, J. V. 2003. Marketing Communications [in Czech: Marketingová komunikace]. Prague: Grada Publishing.

PÍCHA, K. and SKOŘEPA, L. 2018. Preference to Food with a Regional Brand. Quality-Access to Success, 19(162): 134-139.

PÍCHA, K., NAVRÁTIL, J. and ŠVEC, R. 2018. Preference to Local Food vs. Preference to "National” and Regional Food. Journal of Food Products Marketing, 24(2): 125-145.

PITRUNOVÁ, E. and STOKLASA, M. 2018. Online presence of brands in product protective branding. In: Marketing Identity. Smolenice, 6-7 November. Trnava: University of Ss. Cyril and Methodius, pp. 236-247.

PŘIBÍK, O. 2015. Supermarkets offer local products [in Czech: Supermarkety nabízejí lokální produkty]. Zemědělec. [Online]. Available at: https://zemedelec.cz/supermarkety-nabizeji-lokalniprodukty/ [Accessed: 2019, January 23].

PŘIBOVÁ, M., MYNÁŘOVÁ, L., HINDLS, R. and HRONOVÁ, S. 2000. Strategic brand management [in Czech: Strategické ř́zení značky: Brand Management]. Praha: EKOPRESS.

REGIONÁLNí POTRAVINA. 2018. Kloboucký bread roll [in Czech: Klouboucký rohlík]. Regionální potravina. [Online]. Available at: https://www.regionalnipotravina.cz/ocenene-regionalnipotraviny/jihomoravsky-kraj/kloboucky-rohlik/ [Accessed: 2019, January 14].

SAUNDERS, M., LEWIS, P. and THORNHILL, A. 2009. Research methods for business students. Harlow: Pearson Education.

STOKLASA, M. 2015. Possibilities of using regional marking of product in Moravian-Silesian region through cross-cultural marketing. Karviná: Silesian university in Opava, Faculty of Business Administration in Karviná.

STOKLASA, M. and PITRUNOVÁ, E. 2018. Past and future research trends of Regional Brands with accent to technology. Working Paper in Interdisciplinary Economics and Business Research No. 51. Silesian University in Opava, School of Business Administration in Karviná.

ŠPAČKOVÁ, I. 2018. Czechs and Shopping: They report love for national goods, but spend mainly on discounts [in Czech: Češi a nakupování: Hlásají lásku k národnímu zboží, utrácejí však hlavně podle slev]. Aktuálně.cz. [Online]. Available at: https://zpravy.aktualne. cz/finance/nakupovani/cesi-a-nakupovani-hlasaji-lasku-k-narodnimu-zbozi-utraceji-v/ r fc7f5926d78d11e890ecac1f6b220ee8/?utm_source=wwW.seznam.cz\&utm_medium=zboxiku\&redirected=1549485613 [Accessed: 2019, January 3].

TESCO. 2019. Bread roll [in Czech: Rohlík tukový]. [Online]. Available at: https://nakup.itesco.cz/ groceries/cs-CZ/products/2001000151875. [Accessed: 2019, January 14].

THOMAS, B., QUINTAL, V. A. and PHAU, I. 2018. Wine Tourist Engagement With the Winescape: Scale Development and Validation. Journal of Hospitality and Tourism Research, 42(5): 793-828.

TREFA. 2019. Quality food from our region [in Czech: Kvalitní potraviny z našeho regionu]. TREFA. [Online]. Available at: https://www.trefasupermarket.cz/z-naseho-regionu/kvalitni-potraviny-znaseho-regionu/ [Accessed: 2019, January 19]. 
VYSEKALOVÁ, J. 2004. Consumer psychology. How customers buy [in Czech: Psychologie spotrebitele. Jak zákazníci nakupuji]. Praha: Grada Publishing.

ZUFFOVA, E., BOHATOVA, Z. and BUMBALOVA, M. 2017. Evaluation of the Regional Brand Ponitrie from the Perspective of four Elements of the Marketing Mix. In: $20^{\text {th }}$ International Colloquium on Regional Sciences. Kurdějov, 15-16 June. Brno: Masarykova univerzita, pp. 598-605. 